\title{
Speciation Analysis and Ecological Risk Assessment of Antimony in Xikuangshan, Hunan Province
}

\author{
Yan-Hong Liang', Qing-Chuan Liu'²,Yu-Kui Li ${ }^{1}$, Fei Liu ${ }^{1 *}$ \\ ${ }^{1}$ School of Environmental Sciences, Huaibei Normal University, Huaibei 235000, China \\ ${ }^{2}$ School of Food and Biological Engineering, Hefei University and Technology, Hefei, 230000,China
}

Received: 27 April 2020

Accepted: 20 July 2020

\begin{abstract}
Total concentrations and different forms of antimony $(\mathrm{Sb})$ in soils of Laokuang District (LKQ-1, LKQ-2, LKQ-3), Beikuang District (BKQ-4, BKQ-5, BKQ-6) and Nankuang District (NKQ-7, NKQ-8, NKQ-9, NKQ-10) of Xikuangshan, Hunan province, China were analyzed. The soil Sb concentrations in the whole-ore heap of LKQ-1 and the mining land of NKQ-7 were up to 4258 and $3174 \mathrm{mg} / \mathrm{kg}$ respectively, which were both 2000 times above the background soil Sb level in China. In terms of vertical distribution, the $\mathrm{Sb}$ concentrations gradually declined with the rise of soil depth. Tessier's 5-step sequential extraction method showed $\mathrm{Sb}$ mainly existed in stable forms (organic-matter-bound form, residual form), and the available form accounted for $18 \%$. The proportions of different forms ranked as residual form >iron/manganese oxides >organic-matter-bound form >carbonate-bound form $>$ water-soluble form. Vegetation affected the form distribution of $\mathrm{Sb}$ in a complex way and may increase the bioavailability of Sb, so ecological restoration of Sb can be realized through the absorption by vegetation. Analysis of the geoaccumulation index and the potential ecological risk index showed that Xikuangshan was under extremely severe Sb pollution and very serious potential ecological risk. The Sb mining and smelting activities of humans aggravated local Sb pollution.
\end{abstract}

Keywords: Sb, heavy metals, speciation analysis, bioavailability, ecological risk

\section{Introduction}

Antimony ( $\mathrm{Sb}$ ) is a widely-used heavy metal in the industry and has been listed as a priority pollutant by many international organizations because of its potential toxicity and carcinogenicity [1]. Xikuangshan in Lengshuijiang City, Hunan is a major antimony ore mining zone of China. This zone is spread all over with frequent ore mountain activities and mining activities.

*e-mail: liufei888@163.com
The resulting tailings and residues have been naturally heaped for a long time, which occupy farmlands and pollute soils. [2] Xikuangshan is named "capital of antimony in the world" and its antimony reserves rank the first in the world, accounting for $60 \%$ of global $\mathrm{Sb}$ yields. The south-west extending anticlinal strata contain 2.5 to 8 -m-thick three-layer deposits, and about $14 \mathrm{~km}^{2}$ of the mining area is exposed [3]. Xikuangshan is separated into two mining areas in the north and the south respectively. Beikuang District (or the north mining area) is rich in stibnite and cervantite and especially, the cervantite is the sulfide oxidation product intercalated in the stibnite. Nankuang District 
(or the south mining area) mainly produces stibnite. During the long history of mining, a mining-melting pattern has been formed for over a century [4]. The $\mathrm{Sb}$ ore exploration there has driven local economic development, but $\mathrm{Sb}$ and other accompanying elements have also migrated to the surface environment in the mining areas. In addition to soil pollution and lower crop yields, $\mathrm{Sb}$ has also seriously threatened local ecoenvironment and the physical health of residents [5].

Since the chemical behaviors and ecological effects of heavy metal pollutants in soils are very complex, the existing environmental analyses usually focus on measuring the total concentration or total quantity of heavy metals in the environmental medium and on judging the status of soil pollution. However, studies (biological analysis, toxicology experiments) suggest the bioactivity and toxicity of a specific heavy metal are closely related with its activity, migration path, bioavailability and toxicity in the environment or organisms $[6,7]$. The environmental pollution of a heavy metal assessed only from the aspect of total quantity is limited to some extent, since its concrete forms should also be analyzed. Sb commonly exists in the forms of $\mathrm{Sb}(\mathrm{V})$ and $\mathrm{Sb}(\mathrm{III})$ in the environment, and antimonates exist as $\mathrm{Sb}(\mathrm{OH})^{6-}$ in solutions [8, 9]. The forms of $\mathrm{Sb}$ in soils can be divided by the chemical bonding way into the exchangeable form, the carbonate-bound form, the $\mathrm{Fe} / \mathrm{Mn}$ oxide-bound form, the organicmatter-bound form, and the residual form [10]. To study the migrating and transforming rules of heavy metals among different forms, we first extracted the heavy metals in different forms and then measured the concentrations in soils.

The soil heavy metal pollution is commonly assessed by using the geoaccumulation index $\left(I_{\text {geo }}\right)$ and the potential ecological risk index (PER). $I_{\text {geo }}$ uncovers heavy metal pollution in the environment by using the relationship between total heavy metal concentration and the background level, and it also considers the influence of artificial activities in addition to the heavy metal natural distributive characteristics. PER comprehensively reflects environmental chemistry, physiological toxicity and ecology, and considers the toxicity and potential hazard to the environment of heavy metals. PER quantitatively divides the extent of damage and thus is one of the globally-used soil heavy metal assessment methods $[4,11,12]$.

In this study, the soils from various vegetation in Nankuang District, Beikuang District, and Laokuang District (old mining area) of Xikuangshan were studied, and soil Sb total concentrations were measured for characterization of $\mathrm{Sb}$ space-time distributions. The soil $\mathrm{Sb}$ concentrations at different forms were measured using a Tessier 5-step sequential extraction method, and the bioavailability of $\mathrm{Sb}$ was analyzed. The effects of vegetation types on the form variation were studied. Then the environmental risks of $\mathrm{Sb}$ were assessed using $\mathrm{I}_{\text {geo }}$ and PER. This study is expected to contribute to reasonable assessment of local $\mathrm{Sb}$ pollution and to scientifically underlie $\mathrm{Sb}$ pollution treatment.

\section{Materials and Methods}

\section{Sample Collection}

According to the analytical methods in Technical Specification for Soil Environmental Monitoring (HJ/T164-2004), we selected 11 sampling points from 8 soil types (e.g. whole-ore heap, wild land, grassland, farmland) from a control far away from the mining areas (CK), Nankuang District (NKQ), Beikuang District (BKQ), and Laokuang District (LKQ) (Table 1, Fig. 1). Totally 66 samples were collected for measurement of total $\mathrm{Sb}$ concentrations. Three sampling points, including LKQ-2, BKQ-4 and NKQ8 , were selected, from which soils were collected using soil augers at the interval of $5 \mathrm{~cm}$ within the depth of 0-35 cm. Totally 126 soil samples were obtained. Then total $\mathrm{Sb}$ concentrations in the 126 samples were measured, and $\mathrm{Sb}$ concentrations at different forms were detected at the top soils $(0-5 \mathrm{~cm})$ in LKQ-2, BKQ4 and NKQ-8 (totally 18 samples).

\section{Measurement of Total Sb Concentration}

The soil samples were wind-dried naturally, purified by removing small stones and plant residues, and ground through a 200-mesh mortar. Then each sample was either abandoned or adopted as per the quartering method. The soil samples were put into polyethylene bags. Briefly, $0.1000 \mathrm{~g}$ of a soil sample was put into a $250 \mathrm{~mL}$ polytetrafluorethylene beaker. A blank control was set up by using a clean beaker. Then the soil was wetted by adding $1 \mathrm{~mL}$ of pure water via a dropper, and after addition of $5 \mathrm{~mL}$ of $\mathrm{HCl}$ solution, the breaker was put into a digestion stove. When the stove was heated to $80^{\circ} \mathrm{C}$, only $1 \mathrm{~mL}$ of the solution was left. After cooling, $2 \mathrm{~mL}$ of $\mathrm{HCl}$ and $3 \mathrm{~mL}$ of $\mathrm{HNO}_{3}$ were added. Then after the system was heated to $100^{\circ} \mathrm{C}$, only $1 \mathrm{~mL}$ of the solution was left. After cooling, $5 \mathrm{~mL}$ of $\mathrm{HF}$ was added and the system was heated to $120^{\circ} \mathrm{C}$, but only $1 \mathrm{~mL}$ of the solution was left. After cooling, 5 $\mathrm{mL}$ of $\mathrm{HClO}_{4}$ was added and the system was heated to $150^{\circ} \mathrm{C}$ for $3 \mathrm{~h}$ until turning transparent. After cooling, first minor pure water and then $2 \mathrm{~mL}$ of $\mathrm{HNO}_{3}$ were added, and the $\mathrm{HNO}_{3}$ was dissolved after heating at $80^{\circ} \mathrm{C}$. After cooling, the system was transferred to a $100 \mathrm{~mL}$ volumetric flask, which was diluted for further use.

Then $1 \mathrm{~mL}$ of the above solution was collected, added with $1 \mathrm{~mL}$ of a pre-reducer $(10 \% \mathrm{KI}+2 \%$ vitamin $\mathrm{C}$ solution) and diluted with $10 \% \mathrm{HCl}$ to $10 \mathrm{~mL}$ for $1 \mathrm{~h}$ of prereduction. Then total $\mathrm{Sb}$ concentrations were measured using a hydride atomic fluorescence spectrometer (HG-AFS). The quality during digestion and ultimate analysis was controlled by using 
Table 1. Details of sampling points.

\begin{tabular}{|c|c|c|c|}
\hline Name & Latitude and longitude & Land type & Description \\
\hline LKQ-1 & 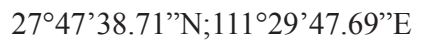 & Whole-ore heap & Near abandoned ore heap \\
\hline LKQ-2 & $27^{\circ} 47^{\prime} 19.41^{\prime \prime} \mathrm{N} ; 111^{\circ} 29^{\prime} 53.41^{\prime \prime} \mathrm{E}$ & Wild land & Wild land near smelting plant \\
\hline LKQ-3 & $27^{\circ} 47^{\prime} 28.97^{\prime \prime} \mathrm{N} ; 111^{\circ} 30^{\prime} 4.55^{\prime \prime} \mathrm{E}$ & Grassland & $2.5 \mathrm{~km}$ from smelting plant \\
\hline BKQ-4 & $27^{\circ} 46^{\prime} 6.09^{\prime \prime} \mathrm{N} ; 111^{\circ} 29^{\prime} 24.20^{\prime \prime} \mathrm{E}$ & Mining land & $0.01 \mathrm{~km}$ from mining plant \\
\hline BKQ-5 & $27^{\circ} 46^{\prime} 24.28^{\prime \prime} \mathrm{N} ; 111^{\circ} 29^{\prime} 36.15^{\prime \prime} \mathrm{E}$ & Smelting land & Smelting land near mining plant \\
\hline BKQ-6 & $27^{\circ} 46^{\prime} 40.73 ” \mathrm{~N} ; 111^{\circ} 29^{\prime} 58.23^{\prime \prime} \mathrm{E}$ & Living area & $4 \mathrm{~km}$ from smelting zone \\
\hline NKQ-7 & $27^{\circ} 44^{\prime} 26.92^{\prime \prime N} ; 111^{\circ} 27^{\prime} 54.58^{\prime \prime} \mathrm{E}$ & Mining land & Inside mining plant \\
\hline NKQ-8 & $27^{\circ} 44^{\prime} 2.23^{\prime \prime} \mathrm{N} ; 111^{\circ} 27^{\prime} 47.63^{\prime \prime} \mathrm{E}$ & Shrubs & $0.5 \mathrm{~km}$ from mining plant \\
\hline NKQ-9 & $27^{\circ} 44^{\prime} 17.43^{\prime \prime} \mathrm{N} ; 111^{\circ} 27^{\prime} 42.51^{\prime \prime} \mathrm{E}$ & Farmland & $1 \mathrm{~km}$ from smelting plant \\
\hline NKQ-10 & $27^{\circ} 44^{\prime} 18.13^{\prime \prime} \mathrm{N} ; 111^{\circ} 27^{\prime} 56.00^{\prime \prime} \mathrm{E}$ & Grassland & $3 \mathrm{~km}$ from mining land \\
\hline $\mathrm{CK}$ & Far away from $\mathrm{Sb}$ ore areas & Wild land & Far from $\mathrm{Sb}$ ore areas \\
\hline
\end{tabular}

national standard substances (GBW07406). The analytic results of soil samples were expressed as dry weights.

\section{Extraction of $\mathrm{Sb}$ in Different Forms}

The $\mathrm{Sb}$ concentrations at soil depth of $0-5 \mathrm{~cm}$ in different forms were measured using a Tessier consecutive extraction method.

(1) Water-soluble form: About $2.000 \mathrm{~g}$ of soil was weighed in a $50 \mathrm{~mL}$ centrifuge tube, added with $20 \mathrm{~mL}$ of pure water, and shaken at room temperature for $2 \mathrm{~h}$. Then after centrifugation, the supernatant was collected into a $25 \mathrm{~mL}$ volumetric flask, and added with
$1 \mathrm{~mL}$ of 1:1 $\mathrm{HCl}$ solution, followed by detection of $\mathrm{Sb}$ concentration via AFS.

(2) Exchangeable form: The residue in step (1) was added with a $16 \mathrm{~mL} / \mathrm{L}$ [11] $\mathrm{MgCl}_{2}$ solution $(\mathrm{pH}=7)$, shaken at room temperature for $2 \mathrm{~h}$, and then centrifuged. The supernatant was collected into a $25 \mathrm{~mL}$ volumetric flask, and added with $1 \mathrm{~mL}$ of the 1:1 $\mathrm{HCl}$ solution, followed by detection of $\mathrm{Sb}$ concentration via AFS.

(3) Carbonate-bound form: The residue in step (2) was added with $16 \mathrm{~mL}$ of a $1 \mathrm{~mol} / \mathrm{L} \mathrm{NaAc}$ solution $(\mathrm{pH}=5)$, oscillated at room temperature for $5 \mathrm{~h}$, and then centrifuged. The supernatant was collected, put into a $25 \mathrm{~mL}$ volumetric flask, and added with $1 \mathrm{ml}$

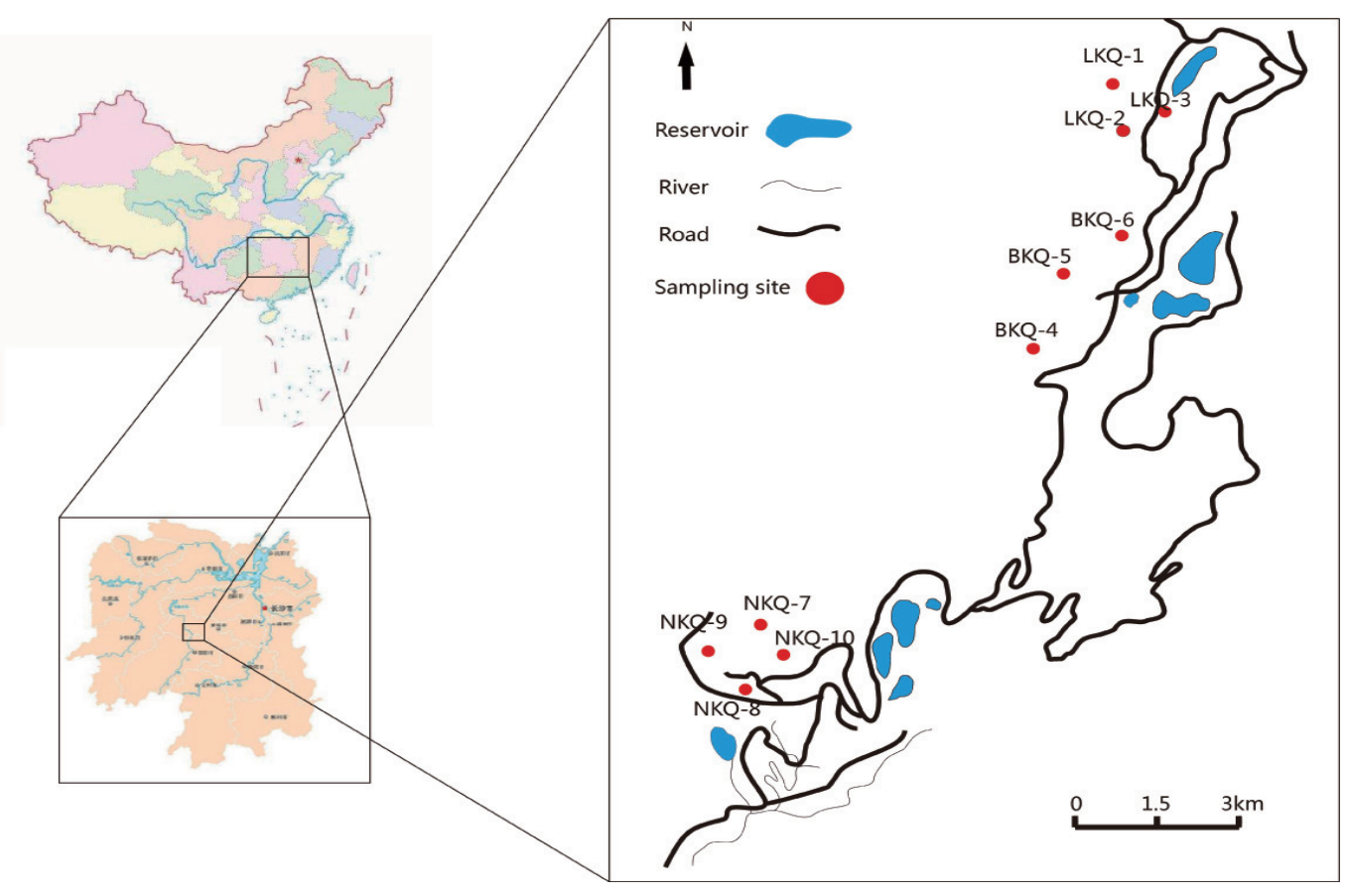

Fig. 1. Map of sampling points. 
of the $1: 1 \mathrm{HCl}$ solution, followed by detection of $\mathrm{Sb}$ concentration via AFS .

(4) Fe/Mn-bound form: The residue in step (3) was added with $20 \mathrm{~mL}$ of a $0.04 \mathrm{~mol} / \mathrm{L} \mathrm{NH}_{2} \mathrm{OH} \cdot \mathrm{HCL} 25 \%$ $(\mathrm{V} / \mathrm{V})$ acetic acid solution, heated in water bath at $96^{\circ} \mathrm{C}$ for $6 \mathrm{~h}$, and stirred discontinuously. Then the supernatant was taken to a $25 \mathrm{~mL}$ volumetric flask, and added with $1 \mathrm{~mL}$ of the $1: 1 \mathrm{HCl}$ solution, followed by detection of $\mathrm{Sb}$ concentration via AFS.

(5) The residue in step (4) was added with $6 \mathrm{ml}$ of $0.02 \mathrm{~mol} / \mathrm{L} \mathrm{HNO}_{3}$ and $10 \mathrm{ml} 30 \% \mathrm{H}_{2} \mathrm{O}_{2}$ solution (adjusted to $\mathrm{pH}=2$ with nitric acid), heated in a $85^{\circ} \mathrm{C}$ water bath for $2 \mathrm{~h}$, and intermittently stirred. Then after addition of $6 \mathrm{ML}$ of $30 \% \mathrm{H}_{2} \mathrm{O}_{2}$ solution $(\mathrm{pH}=2)$, the mixed system was further heated in the $85^{\circ} \mathrm{C}$ water bath and stirred for $3 \mathrm{~h}$. After that, the system was cool downed, added with $20 \%(\mathrm{w} / \mathrm{V})$ nitric acid solution of $3.2 \mathrm{~mol} / \mathrm{L}$ ammonium acetate, vibrate for $30 \mathrm{~min}$, and centrifuged. Finally, the supernatant was collected into a $25 \mathrm{ml}$ volumetric flask, and added with 1 content of antimony in ML 1:1 $\mathrm{HCl}$ solution, followed by detection of $\mathrm{Sb}$ concentration via AFS.

(6) Residual form: The residual $\mathrm{Sb}$ concentration was calculated as total Sb concentration - total concentrations of the above forms.

\section{Evaluation Methods}

(1) $I_{\text {geo }}$ According to the topsoil background levels in Hunan, the local ecological risk of $\mathrm{Sb}$ was assessed by using $I_{g e o}$ :

$$
I_{\text {geo }}=\log _{2}\left[C_{i} /\left(K \times C_{n}^{i}\right)\right]
$$

...where $C_{i}$ is the measured $\mathrm{Sb}$ concentration in the environment; $K$ is the modification index (usually 1.5), and $C_{n}{ }^{i}$ is the background level of the heavy metal in the environment $(2.98 \mathrm{mg} / \mathrm{kg}$ in Hunan). Muller divided $I_{\text {geo }}$ into seven grades $[13,14$ (2) PER The PER index proposed by Hanson [15, 16] integrates heavy metal concentrations, ecological effects, environmental effects and toxicology, and quantitatively divides the degree of potential risks. The PER index of concrete heavy metal pollution can be expressed as:

$$
E_{r}^{i}=T_{r}^{i} * C_{f}^{i}=T_{r}^{i} * \frac{D_{i}}{B_{i}}
$$

..where $E_{r}{ }^{i}$ is the PER factor of a given element; $T_{r}^{i}$ is its toxicity index (which is 7 [17]); $C_{r}^{i}$ is the pollution factor; $D_{i}$ is the average content of the target element; $B_{i}$ is the standard reference level in the industry $\left(B_{i}=1.5\right.$ for $\left.\mathrm{Sb}[18,19]\right) . E_{r}{ }^{i}<40,40 \leq E_{r}{ }^{i}<80,80 \leq E_{r}{ }^{i}<160$, $160 \leq E_{r}^{i}<320$, and $E_{r}^{i}>320$ mean low, modest, high, severe and very severe PER respectively [20, 21].

\section{Data Processing}

All data were expressed as mean \pm standard deviation. Data were preprocessed on Excel 2003. Statistical analysis was conducted on SPSS20, and plotting was finished on Origin7.0.

\section{Results and Discussion}

\section{Distribution of Heavy Metals in Soil}

The total $\mathrm{Sb}$ concentrations in the topsoils (0-5 cm) of LKQ-1, NKQ-7 and BKQ-6 were listed in Fig. 2. Clearly, the average $\mathrm{Sb}$ concentrations in all three sampling sites were about 2000 times the background soil $\mathrm{Sb}$ concentration of China $(0.38-2.98 \mathrm{mg} / \mathrm{kg})$. Specifically, the average soil $\mathrm{Sb}$ concentrations in LKQ-1 and NKQ-7 were up to 4258 and $3174 \mathrm{mg} / \mathrm{kg}$ respectively. The result in BKQ-6 was the lowest among the three, but was yet 10 times significantly higher than that of the control $(p<0.05)$. Generally, the $\mathrm{Sb}$ concentrations in BKQ

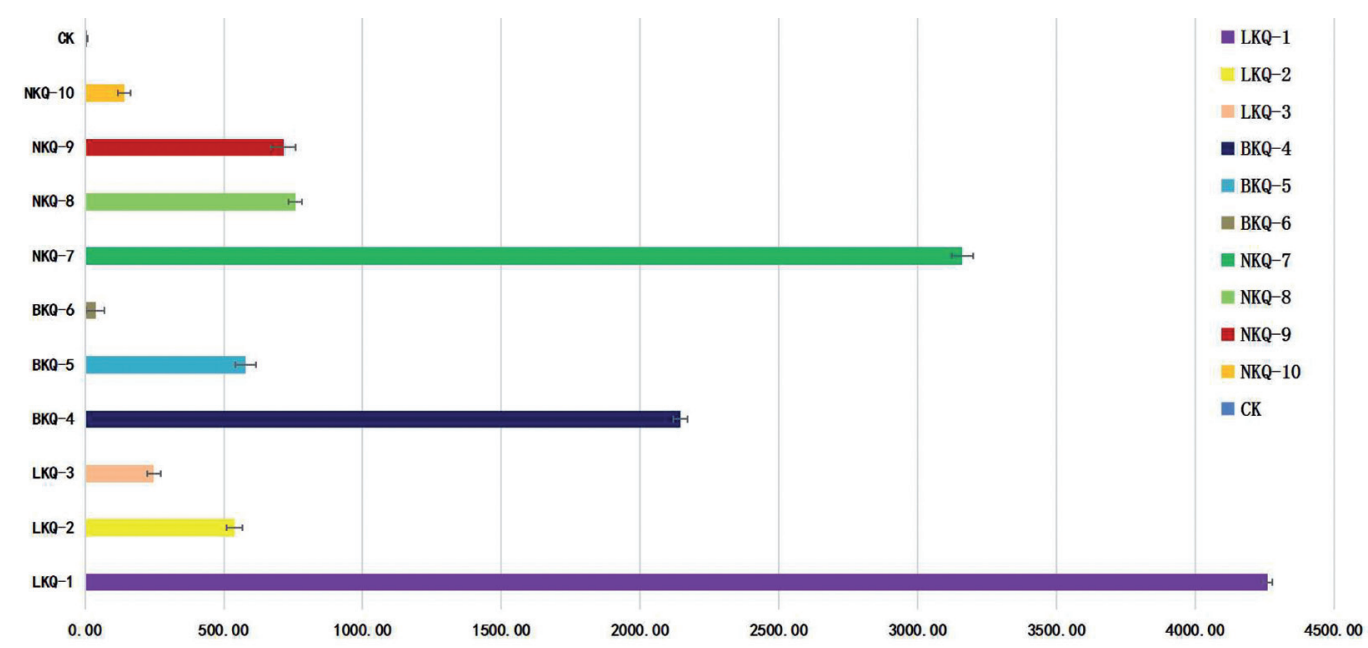

Fig. 2. Total $\mathrm{Sb}$ concentrations in topsoils $(0-5 \mathrm{~cm})$ at different sampling sites. 


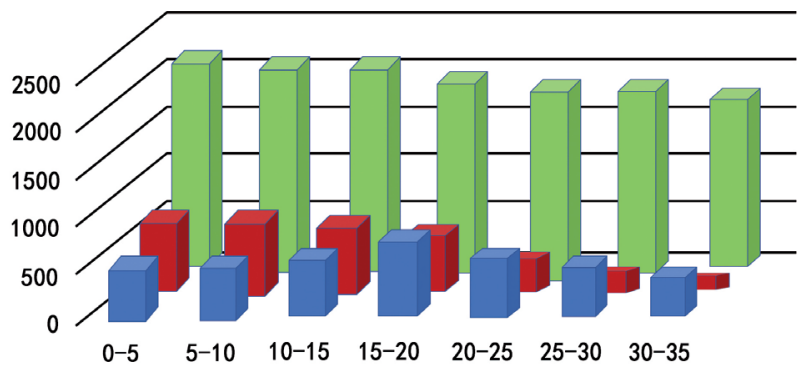

- LKQ-2 = NKQ-8 $=$ BKQ-4

Fig. 3 Vertical distributions of soil Sb concentrations.

were significantly higher than those in NKQ and LKQ $(P<0.05)$ (Fig. 2, Table 1). The $\mathrm{Sb}$ concentrations in BKQ-4 and NKQ-7 were higher as these two sites were closer to whole-ore heaps, mining lands and smelting lands, and the $\mathrm{Sb}$ concentrations in whole-ore heaps and mining lands were significantly higher than those in grasslands and living areas $(P<0.05)$. The $\mathrm{Sb}$ concentrations in whole-ore heaps were 17 times higher than those in grasslands of the same district and mainly originated from mining, smelting and slag heaping. On the contrary, the soil Sb concentrations in the farmland around the smelting plant were significantly different $(P<0.05)$, as the $\mathrm{Sb}$ concentrations in areas closer to the ore heaps were higher.

As the distance from the $\mathrm{Sb}$ smelting plant was farther, the total soil $\mathrm{Sb}$ concentration declined, since the $\mathrm{Sb}$ in vivo of plants was largely absorbed from atmospheric precipitation rather than from soils. In the Dahlsson copper/tungsten mine of South Korea, the soil $\mathrm{Sb}$ concentrations dropped with the increasing distance from mining areas [22], which is similar to our findings. Thus, mining activities indeed affect the $\mathrm{Sb}$ distribution in the nature. In terms of land types, the soil $\mathrm{Sb}$ concentrations in vegetation-covered areas, such as shrubs (NKQ-8) and grasslands (LKQ-3, NKQ10 ), were significantly lower than in vegetation-less areas, such as wild lands (LKQ-2) and mining areas (BKQ-4, NKQ-7) $(P<0.05)$. As reported, the $\mathrm{Sb}$ concentrations gradually declined from the edges of grasslands to the center of shrubs, and the $\mathrm{Sb}$ diffusion was affected by the natural resistance [23] .

The vertical distributions of soil $\mathrm{Sb}$ concentrations in LKQ-2, BKQ-4 and NKQ-8 were shown in Fig. 3. Clearly, the Sb concentrations in BKQ-4 and NKQ8 gradually dropped with the increment of soil depth. The $\mathrm{Sb}$ concentration in LKQ-2 peaked at the depth of $15 \mathrm{~cm}$ and then gradually dropped. It was indicated $\mathrm{Sb}$ was usually enriched and unmovable in topsoils, and human exploitation activities largely affected the soil $\mathrm{Sb}$ distribution in Xikuangshan. A study in Forge Bay of New Zealand showed that heavy metals can enter underground through the channels formed from the interaction between surface water or groundwater and rocks, which thereby changed the vertical distributions of heavy metals in soils [24] .

The antimony reserves in China rank the first in the world, and Xikuangshan in Hunan of China is wellknown as the capital of antimony. However, the $\mathrm{Sb}$ mining and smelting activities as well as the extensive use of $\mathrm{Sb}$ in various industries have led to the entrance of abundant antimony into the environment, causing antimony pollution. The $\mathrm{Sb}$ pollution in the environment mainly originates from two sources: natural pollution and man-made pollution. The natural pollution of $\mathrm{Sb}$ originates from $\mathrm{Sb}$-enriched areas (e.g. Sb mining areas), which after volcanic eruption or rock weathering will result in severe elevation of $\mathrm{Sb}$ concentration in the environment. The man-made pollution mainly results from three aspects: Sb-containing domestic waste, $\mathrm{Sb}$ mining (dust, waste water, waste residues), and combustion of Sb-containing fuels [10, 12]. In the process of mining and smelting, the process is simple, the technology is backward, and the energy

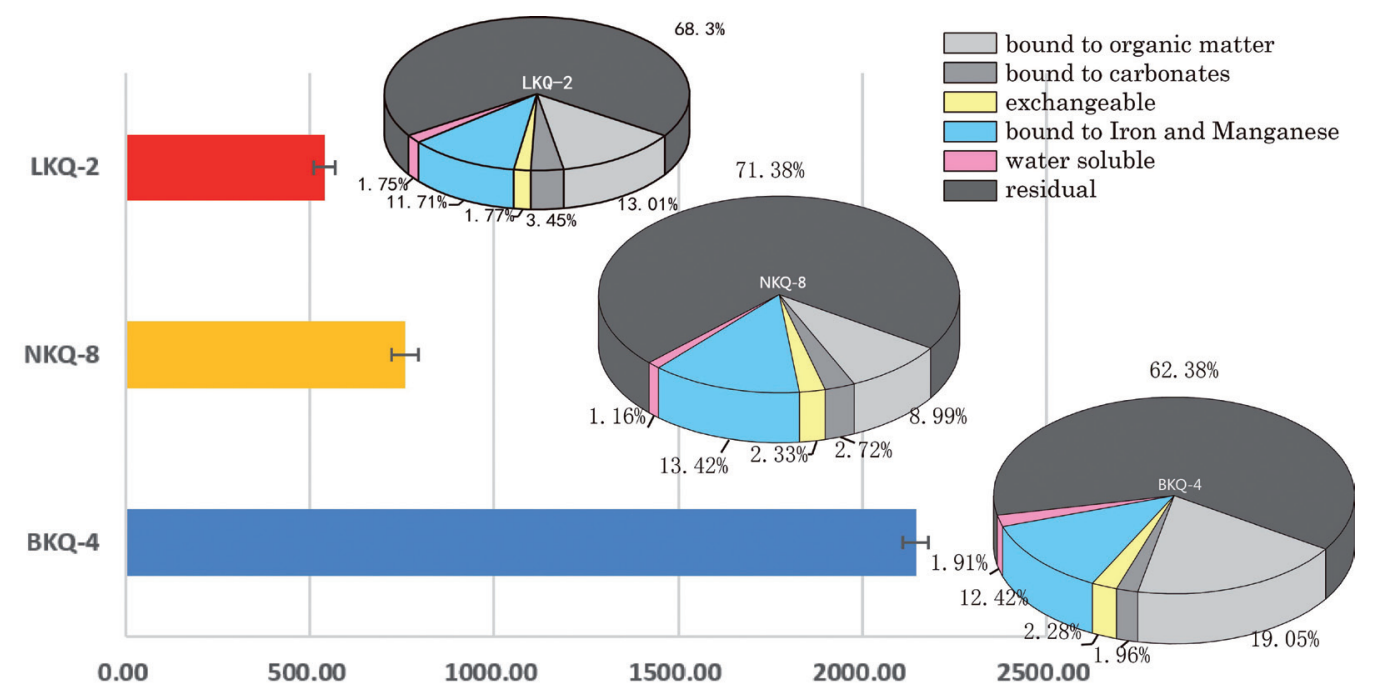

Fig. 4. Distribution of different forms of Sb in LKQ-2, NKQ-6 and BKQ-4. 
Table 2. $I_{g e o}$ and PER index at different sampling points.

\begin{tabular}{|c|c|c|c|c|c|c|c|c|c|c|c|}
\hline $\begin{array}{c}\text { Sampling } \\
\text { site }\end{array}$ & LKQ-1 & LKQ-2 & LKQ-3 & BKQ-4 & BKQ-5 & BKQ-6 & NKQ-7 & NKQ-8 & NKQ-9 & NKQ-10 & CK \\
\hline \multirow{2}{*}{$I_{\text {geo }}$} & 9.9 & 6.91 & 5.79 & 8.91 & 7.01 & 3.04 & 9.74 & 7.41 & 7.32 & 4.98 & -0.38 \\
\cline { 2 - 32 } & $\begin{array}{c}\text { Very } \\
\text { severe }\end{array}$ & $\begin{array}{c}\text { Very } \\
\text { severe }\end{array}$ & $\begin{array}{c}\text { Very } \\
\text { severe }\end{array}$ & $\begin{array}{c}\text { Very } \\
\text { severe }\end{array}$ & $\begin{array}{c}\text { Very } \\
\text { severe }\end{array}$ & Severe & $\begin{array}{c}\text { Very } \\
\text { severe }\end{array}$ & $\begin{array}{c}\text { Very } \\
\text { severe }\end{array}$ & $\begin{array}{c}\text { Very } \\
\text { severe }\end{array}$ & $\begin{array}{c}\text { Very } \\
\text { severe }\end{array}$ & No \\
\hline \multirow{2}{*}{$E_{r}^{i}$} & 19877.20 & 2513.67 & 1157.52 & 10010.05 & 2697.15 & 171.08 & 14749.42 & 3535.84 & 3333.63 & 658.51 & 16.05 \\
\cline { 2 - 13 } & High & High & High & High & High & Extreme & High & High & High & High & Low \\
\hline
\end{tabular}

consumption is large, which will lead to a low recovery rate of heavy metals. During the smelting process, some heavy metals also rose with the steam, and the smoke and dust entered the atmospheric environment. The sedimentation effect expanded the pollution range and caused severe damage and impact on the surrounding bad environment $[25,26]$.

Reportedly, the water-soluble, carbonate-bound, and exchangeable forms of heavy metals can also be directly absorbed and utilized by plants [27]. The organic-matter-bound form cannot be easily used and the residual form is almost unusable by organisms. The Tessier sequential extraction showed (Fig. 4) $\mathrm{Sb}$ in the mining areas mainly existed in the residual form. The proportions of residual Sb in LKQ-2, NKQ-8 and BKQ4 were $68.3 \%, 71.38 \%$ and $62.38 \%$ respectively. The other dominant forms were successively the Fe/Mnbound form (reducible form, 11.71\%, 13.42\%, 12.42\%), organic-matter-bound form (oxidizable form, 13.01\%, $8.99 \%, 19.05 \%)$, and carbonate-bound form $(3.45 \%$, $2.72 \%, 1.96 \%)$, while the exchangeable form $(1.77 \%$, $2.33 \%, 2.28 \%)$ and water-soluble form $(1.75 \%, 1.61 \%$, $1.91 \%$ ) occupied minor proportions. These results are consistent with the rank from other studies: residual form $>\mathrm{Fe} / \mathrm{Mn}$-bound form, organic-matter-bound form >carbonate-bound form >water-soluble form. As reported, the soil $\mathrm{Sb}$ in Denari National Park and Conservation Zone mainly existed as oxides [28].

In Xikuangshan, $\mathrm{Sb}$ mainly existed in steady forms (organic-matter-bound form, residual form), and the available form, which can be easily utilized by organisms, only accounted for $18 \%$. The vegetation in NKQ-8 was shrubs, and the proportion of the exchangeable form increased significantly by $32 \%$ compared with LKQ-2 $(P<0.05)$, which may be largely attributed to the presence of shrubs. As reported, plant growth can alter some physicochemical properties and biological characteristics of soils [29, 30]. Growing roots can produce large amounts of secretions, such as sugars, proteins, small molecular acids, phenols, ketones, auxins, steroids, etc [31, 32]. The production of root exudates is an adaptive mechanism formed by plants during long-term evolution and growth. This mechanism is a micro-ecological process at the root interface of plants, which can promote the establishment of resistance mechanisms and release secretions by plants under external stress such as heavy metals. Substances can induce directional changes in the microbial community structure of plant roots, and thus affect the precipitation-dissolution, oxidation-reduction, complexation reaction and fixationactivation of heavy metals at the root interface, thereby increasing or decreasing the bioavailability of heavy metal elements. Root exudates can significantly change the physical, chemical, and biological properties of the root-soil interface [33]. According to current research reports, planting large numbers of plants in contaminated areas can alleviate the toxicity of heavy metal elements [34]. The $\mathrm{Sb}$ in the polluted soils near the smelting plant mainly existed in $\mathrm{Sb}(\mathrm{V})$ and $\mathrm{Sb}(\mathrm{III})$ [23]. However, soil $\mathrm{pH}$ increased along with the application of soil modifiers. When soils changed from weak acidity to weak alkalinity, the forms of Sb in soils changed accordingly and the proportion of bioavailable $\mathrm{Sb}$ rose, leading to higher ecological risks. In response, the soil $\mathrm{Sb}$ concentrations can be lowered through the absorption by plants, which can activate $\mathrm{Sb}$ in soils [27]. Sb form analysis in the three sampling points showed that the environmental behaviors, migration/ converting ability and bioavailability of heavy metals in soils largely depended on the forms of heavy metals. Form analysis is the basis of bioavailability, while bioavailability is the extension of form analysis in a specific field.

\section{Ecological Risk Assessment of Sb}

Results of $I_{g e o}$ and ecological risks at different sampling points were listed in Table 2. High PER was found in all sampling points, except for the control. The PER index $E_{r}^{i}$ is highly correlated with $I_{\text {geo }}$ $\left(\mathrm{R}^{2}=0.7473\right)$. The Hakanson toxicity factor, proposed in 1980, has been used to evaluate the ecological risks of $\mathrm{Cr}, \mathrm{Zn}, \mathrm{Cu}, \mathrm{Pb}, \mathrm{As}, \mathrm{Cd}$ and $\mathrm{Hg}$. However, since the PER index of $\mathrm{Sb}$ has always been queried, there is no definite value about the toxicity risk of Sb. The investigation into $\mathrm{Sb}$ in freshwater wetland samples showed the toxicity coefficient of Sb was 10, which was used to assess the PERs of mid- and down-stream plains of Changjiang River [35]. Study on the ecological risks of Xikuangshan in Hunan showed the environmental information of $E_{r}^{i}$ was similar to EF and $I_{\text {geo }}$, but such similarity was unrelated to soil types [17]. 


\section{Conclusion}

(1) The use of geological accumulation index and potential ecological risk index to analyze and evaluate the ecological risk of Tin mine is consistent, and there are serious ecological risks here.

(2) From the aspect of horizontal distribution, the antimony contents in ore heap and mining area are significantly higher than that in living area. Vertical distribution, soil Sb concentration LKQ first increased, then decreased, but NKQ soil Sb concentration decreased with the increase of soil depth, indicating that soil $\mathrm{Sb}$ concentration mining and smelting activities seriously affect humans.

(3) Tessier five-step extraction method shows that $\mathrm{Sb}$ mainly exists in stable forms (organic binding form and residual form). The proportions of different forms rank as residual form >iron and manganese oxidation binding form >organic binding form $>$ carbonate binding form $>$ water-soluble form. Vegetation affects the morphological distribution of $\mathrm{Sb}$ in complex ways, which may increase the bioavailability of $\mathrm{Sb}$ and thus achieve the ecological restoration of $\mathrm{Sb}$ through vegetation absorption.

\section{Acknowledgements}

This work was funded by the National Science Foundation of China (No. 41371444), the Innovation Team of Scientific Research Platform of Anhui Province, China. No. KJ2015TD001. the Natural Science Foundation from Educational Commission of Anhui Province (No. KJ2016B013, KJ2017ZD55).

\section{Conflict of Interest}

There is no potential conflict of interest in what is stated herein.

\section{References}

1. HE M., WANG X., WU F., FU Z. Antimony pollution in China, Science of The Total Environment. 421-422, 41, 2012.

2. YANG H., HE M. Distribution and Speciation of Selenium, Antimony, and Arsenic in Soils and Sediments Around the Area of Xikuangshan (China), CLEAN - Soil, Air, Water. 44 (11), 1538, 2016.

3. HE M. Distribution and phytoavailability of antimony at an antimony mining and smelting area, Hunan, China, Environ Geochem Health. 29 (3), 209, 2007.

4. LIU F., LE X. C., MCKNIGHT-WHITFORD A., XIA Y., WU F., ELSWICK E., JOHNSON C. C., ZHU C. Antimony speciation and contamination of waters in the Xikuangshan antimony mining and smelting area, China, Environ Geochem Health. 32 (5), 401, 2010.

5. FU Z., WU F., MO C., LIU B., ZHU J., DENG Q., LIAO H., ZHANG Y. Bioaccumulation of antimony, arsenic, and mercury in the vicinities of a large antimony mine, China, Microchemical Journal. 97 (1), 12, 2011.

6. OKKENHAUG G., ZHU Y.-G., LUO L., LEI M., LI X., MULDER J. Distribution, speciation and availability of antimony $(\mathrm{Sb})$ in soils and terrestrial plants from an active Sb mining area, Environmental Pollution. 159 (10), 2427, 2011.

7. LI Y., LIU F., ZHOU X., WANG X., LIU Q., ZHU P., ZHANG L., SUN C. Distribution and Ecological Risk Assessment of Heavy Metals in Sediments in Chinese Collapsed Lakes, Polish Journal of Environmental Studies. 26 (1), 181, 2017.

8. FILELLA M., BELZILE N., CHEN Y.-W. Antimony in the environment: a review focused on natural waters, EarthScience Reviews. 57 (1-2), 125, 2002.

9. NGUYEN V. K., PARK Y., LEE T. Microbial antimonate reduction with a solid-state electrode as the sole electron donor: A novel approach for antimony bioremediation, J Hazard Mater. 377, 179, 2019.

10. HU X., HE M., LI S., GUO X. The leaching characteristics and changes in the leached layer of antimony-bearing ores from China, Journal of Geochemical Exploration. 176, 76, 2017.

11. NRIAGU J. O., PACYNA J. M. Quantitative assessment of worldwide contamination of air, water and soils by trace metals, Nature. 333 (6169), 134, 1988.

12. CHU J., MAO J., HE M. Anthropogenic antimony flow analysis and evaluation in China, Sci Total Environ. 683, 659, 2019.

13. MULLER G. Index of Geoaccumulation in Sediments of the Rhine River, Geo J. 2, 109, 1969.

14. ZHU D., WEI Y., ZHAO Y., WANG Q., HAN J. Heavy Metal Pollution and Ecological Risk Assessment of the Agriculture Soil in Xunyang Mining Area, Shaanxi Province, Northwestern China, Bulletin of Environmental Contamination and Toxicology. 101, 2018.

15. HAKANSON L.H., HAKANSONN L. An ecological risk index for aquatic pollution control.a sedimentological approach, Water Research. 14, 26, 1980.

16. HUANG J.-H., LIU W.-C., ZENG G.-M., LI F., HUANG X.-L., GU Y.-L., SHI L.-X., SHI Y.-H., WAN J. An exploration of spatial human health risk assessment of soil toxic metals under different land uses using sequential indicator simulation, Ecotoxicology and Environmental Safety. 129, 199, 2016.

17. WANG N., WANG A., KONG L., HE M. Calculation and application of $\mathrm{Sb}$ toxicity coefficient for potential ecological risk assessment, Sci Total Environ. 610-611, $167,2018$.

18. BOWEN H.J.M. Trace Elements in Biochemistry, 1966.

19. ZHUANG W., WANG Q., TANG L., LIU J., YUE W., LIU Y., ZHOU F., CHEN Q., WANG M. A new ecological risk assessment index for metal elements in sediments based on receptor model, speciation, and toxicity coefficient by taking the Nansihu Lake as an example, Ecological Indicators. 89, 725, 2018.

20. BLANCHARD D., LOUIS N., ABDOURAHIMI, DANIEL B., SAÏDOU, NDJANA NKOULOU II J., BONIFACE K., GODFROY K. Environmental Pollution by Heavy Metals in the Gold Mining Region of East Cameroon, American journal of environmental sciences. 14, 2018.

21. LIYIN Q., HUANG H., XIA F., LIU Y., DAHLGREN R., ZHANG M., MEI K. Risk analysis of heavy metal concentration in surface waters across the rural- 
urbaninterface of the Wen-Rui Tang River, China, Environmental pollution (Barking, Essex : 1987). 237, 639, 2018.

22. JUNG M.C., THORNTON I., CHON H. T. Arsenic, $\mathrm{Sb}$ and $\mathrm{Bi}$ contamination of soils, plants, waters and sediments in the vicinity of the Dalsung $\mathrm{Cu}-\mathrm{W}$ mine in Korea, Sci Total Environ. 295 (1-3), 81, 2002.

23. TSCHAN M., ROBINSON B. H., SCHULIN R. Antimony in the soil - plant system - a review, Environmental Chemistry. 6 (2), 2009.

24. WILSON N. J., CRAW D., HUNTER K. Contributions of discharges from a historic antimony mine to metalloid content of river waters, Marlborough, New Zealand, Journal of Geochemical Exploration. 84 (3), 127, 2004.

25. KRISHNA A. K., MOHAN K. R. Distribution, correlation, ecological and health risk assessment of heavy metal contamination in surface soils around an industrial area, Hyderabad, India, Environ Earth Sci. 75 (5), 2016.

26. DANG Z., LIU C., HAIGH M. J. Mobility of heavy metals associated with the natural weathering of coal mine spoils, Environ Pollut. 118 (3), 419, 2002.

27. DAI Y., NASIR M., ZHANG Y., WU H., GUO H., LV J. Comparison of DGT with traditional methods for assessing cadmium bioavailability to Brassica chinensis in different soils, Sci Rep. 7 (1), 14206, 2017.

28. RITCHIE V.J., ILGEN A.G., MUELLER S.H., TRAINOR T.P., GOLDFARB R.J. Mobility and chemical fate of antimony and arsenic in historic mining environments of the Kantishna Hills district, Denali National Park and Preserve, Alaska, Chemical Geology. 335, 172, 2013.
29. SUN X., LI B., HAN F., XIAO E., WANG Q., XIAO T., SUN W. Vegetation type impacts microbial interaction with antimony contaminants in a mining-contaminated soil environment, Environ Pollut. 252 (Pt B), 1872, 2019.

30. GANDOIS L., AGNAN Y., LEBLOND S., SéJALONDELMAS N., LE ROUX G., PROBST A. Use of geochemical signatures, including rare earth elements, in mosses and lichens to assess spatial integration and the influence of forest environment, Atmospheric Environment. 95, 96, 2014.

31. DIETZ S., HERZ K., GORZOLKA K., JANDT U., BRUELHEIDE H., SCHEEL D. Root exudate composition of grass and forb species in natural grasslands, Sci Rep. 10 (1), 10691, 2020.

32. CENTOFANTI T., SAYERS Z., CABELLO-CONEJO M.I., KIDD P., NISHIZAWA N. K., KAKEI Y., DAVIS A.P., SICHER R.C., CHANEY R.L. Xylem exudate composition and root-to-shoot nickel translocation in Alyssum species, Plant Soil. 373 (1-2), 59, 2013.

33. CAI F., REN J., TAO S., WANG X. Uptake, translocation and transformation of antimony in rice (Oryza sativa L.) seedlings, Environ Pollut. 209, 169, 2016.

34. YU H.Y., WANG X.Q., LI F.B., LI B., LIU C.P., WANG Q., LEI J. Arsenic mobility and bioavailability in paddy soil under iron compound amendments at different growth stages of rice, Environmental Pollution. 224, 136, 2017.

35. YAO C., JIANG X., CHE F., WANG K., ZHAO L. Antimony speciation and potential ecological risk of metal(loid)s in plain wetlands in the lower Yangtze River valley, China, Chemosphere. 218, 1114, 2019. 